\title{
Sustainability of groundwater resources of weathered and fractured schists in the rural areas of Galicia (Spain)
}

\author{
Javier Samper $^{1}$ (1) $\cdot$ Acacia Naves $^{1} \cdot$ Bruno Pisani $^{1} \cdot$ Jorge Dafonte $^{2} \cdot$ Luis Montenegro $^{1} \cdot$ Aitor García-Tomillo $^{1}$
}

Received: 7 April 2021 / Accepted: 25 January 2022 / Published online: 18 February 2022

(c) The Author(s) 2022

\begin{abstract}
Water supply deficits in droughts, groundwater pollution and climate change are the main challenges for the sustainability of groundwater resources from hard-rock aquifers in rural areas of Galicia (Spain). Here, we address the sustainability of groundwater resources of weathered and fractured schists in the rural areas of the Abegondo municipality. The conceptualization of the hydrogeology of the study area includes: (1) The weathered schist (regolith), (2) The decompressed highly fractured schist layer; and (3) An underlying slightly fractured schist. Groundwater flows mostly through the regolith and the highly fractured rock. Rainfall infiltration is the source of aquifer recharge. Groundwater discharges in seepage areas, springs and along creeks and valleys. The water table is generally shallow and shows seasonal oscillations of up to $4 \mathrm{~m}$. The equivalent transmissivity of the regolith and the highly fractured schist ranges from 15 to $35 \mathrm{~m}^{2} /$ days. The electrical resistivity tomography identifies a shallow water table and attests that the contact of the highly fractured schist and the slightly fractured schist is highly heterogeneous. Groundwater resources were quantified with a hydrological water balance model. The mean annual recharge is about $185 \mathrm{~mm}$. Groundwater recharge at the end of the twenty-first century could decrease from 6 to $10 \%$ due to climate change. The decline in groundwater table could aggravate the shortages during droughts. Groundwater quality data show bacteriological and nitrate contamination due to the poor management of the manure in the fields and occasional discharges of slurry from pig and mink farms. Groundwater management and protection actions are proposed to prevent groundwater pollution and achieve a sustainable groundwater supply in the study area.
\end{abstract}

Keywords Sustainability $\cdot$ Rural water supply $\cdot$ Groundwater resources $\cdot$ Schists $\cdot$ Climate change $\cdot$ Galicia $\cdot$ Groundwater pollution

\section{Introduction}

The European regulations concerning the water protection and management (Directive 2000/60/EC) and the quality of water for human consumption (Directive 98/83/EC) pose a great challenge for water supply in dispersed rural communities such as those of Galicia in the northwestern corner of the Iberian Peninsula (Fig. 1) (Naves et al. 2019, 2021). The technical and economic feasibility of centralized

Javier Samper

jsamper@udc.es

1 Centro de Investigaciones Científicas Avanzadas (CICA), ETS Ingenieros de Caminos, Canales y Puertos, Universidade da Coruña, A Coruña, Spain

2 GI-1716, Proyectos y Planificación, Escuela Politécnica Superior de Ingeniería, Universidade de Santiago de Compostela, Lugo, Spain infrastructures in these regions is severely limited by the distance to highly populated areas and the large investments required to undertake them. Local people have developed spontaneously autonomous water supply systems based on spring catchments, shallow dug wells and deep drilled wells. More than 650,000 people rely on groundwater supply from hard-rock aquifers through this kind of solutions in the rural areas of Galicia (Naves and Varela-Álvarez 2021).

Hard rocks generally show a large spatial heterogeneity in both vertical and horizontal directions, which causes a large spatial variability in the hydrogeological parameters. The statistical structure of the spatial variability can be derived with adjoint-state cross-validation methods (Samper and Neuman 1989). Hard rock aquifers usually present: (1) A shallow regolith layer with clay-rich material derived from the in situ weathering of the bedrock; (2) A fractured rock layer, which often presents a dense horizontal network of fractures in the first few meters and a 


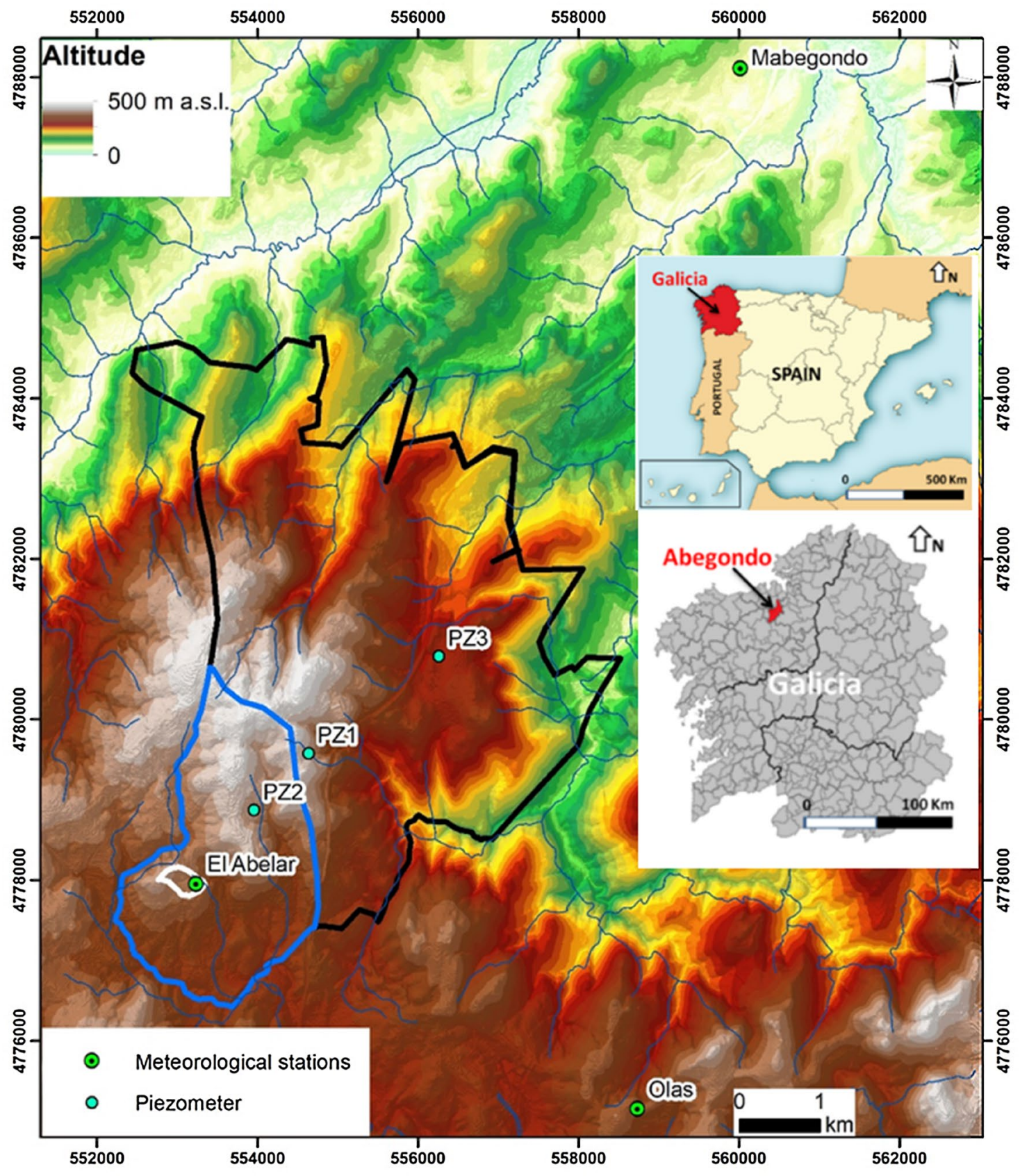

Fig. 1 Location of the study area in the Abegondo municipality (Galicia, Spain). The map includes the Digital Terrain Model and the drainage network, dividing the area which drains to the north to the Mero and Barcés rivers (black line) and the area which drains to the

depth-decreasing density of subhorizontal and subvertical fractures (Taylor and Howard 2000); and (3) The less-fractured rock basement which is permeable only when tectonic fracture zones are present (Krasny 2002; Lubczynski and Gurwin 2005; Dewandel et al. 2006; Espinha et al. 2013). The proposed conceptualizations of groundwater flow in hard rocks include (Berkowitz 2002; Selroos et al. 2002): double porosity models (Barenblatt et al. 1960), south and tributes to the Tambre river (blue line). The location of the meteorological stations, the pilot experimental basin of El Abelar and the three piezometers (PZ1, PZ2, and PZ3) of the piezometric monitoring network are also indicated

discrete fracture models (Lee and Farmer 1993; Long et al. 1982; Molinero and Samper 2004; Molinero et al. 2004; Dong et al. 2019), parallel plate models (Bear 1993; Lee and Farmer 1993) and equivalent porous media models (Lubczynski and Gurwin 2005; Dewandel et al. 2006).

The main challenges for the sustainable groundwater supply in the rural areas of Galicia include: (1) Low guarantee of water supply in dry periods, (2) Groundwater quality 
deterioration and (3) Deficiencies in the governance of groundwater use and sewage water treatment (Naves et al. 2019; Life Rural Supplies 2020; Naves and Varela-Álvarez 2021).

Previous hydrological research and water resources assessment were performed in the Abelar pilot watershed in Abegondo by Soto et al. (2005) and Rodríguez-Suárez et al. (2011, 2014) (Fig. 1). This small watershed has a surface area of about 10.7 ha. It was equipped with two meteorological stations, two piezometers and a streamflow gauging station (Soto et al. 2005; Rodríguez-Suárez et al. 2011, 2014). The results reported by Rodríguez-Suárez et al. $(2011,2014)$ show that fast-growing trees reduces the availability of the water resources in dry periods, leading to a decline of the water table and the drying up of springs and small creeks.

Climate change could aggravate the current problems of water supply guarantee in Galicia during drought periods. Raposo et al. (2013) evaluated the impacts of climate change on groundwater resources in Galicia using a hydrological model and the meteorological series of the PRUDENCE climate project (Christensen et al. 2007). Raposo et al. (2013) reported that groundwater recharge could concentrate in the winter and decrease in the summer and the autumn.

There is a concern about the chemical and microbiological quality of groundwater supply in rural areas due to the lack of proper control of the water quality by well owners. Agricultural contamination is often a pressure on the groundwater chemical status where nitrate is the main concern for groundwater quality (EC 2010). Other risks for groundwater contamination include the poor management of the manure in the fields, the discharge of slurry from farms and the inadequate planning of land use, which does not account for groundwater protection.

Here we address the sustainability of groundwater resources of weathered and fractured schists in the rural areas of Abegondo (Galicia, Spain). The available topographic, meteorological, geological, electric resistivity tomography (ERT), piezometric, streamflow and hydrochemical data have been integrated into the proposed conceptualization of the hydrogeology of the study area. The impact of climate change on groundwater resources is quantified with a hydrological water balance model. The study includes also the assessment of groundwater chemistry and pollution. Finally, recommendations are given for groundwater management and protection to prevent groundwater pollution and achieve a sustainable groundwater supply.

\section{Description of the study area}

The study area is located in the highest part of the Abegondo municipality (Fig. 1). It covers a surface area of $29 \mathrm{~km}^{2}$ with altitudes ranging from 250 to $409 \mathrm{~m}$ a.s.l. The climate in the region is wet oceanic with relatively abundant rainfall. It is classified as Csb, temperate with dry or temperate summer, according to Köppen Climate Classification system (AEMET and IM 2011). The autumn and the winter are the rainiest seasons. The complete weather station at the Agricultural Research Center of Mabegondo is located $4 \mathrm{~km}$ at the north of the study area at an elevation of $94 \mathrm{~m}$, which is significantly lower than that of the study area (Fig. 1). The average annual temperature and precipitation in this station are equal to $12.3^{\circ} \mathrm{C}$ and $1133 \mathrm{~mm}$, respectively. The Olas weather station is located $6 \mathrm{~km}$ at the south boundary of the study area at an elevation of $401 \mathrm{~m}$ (Fig. 1), which is similar to the altitude of the elevated zones of the study area. The average annual precipitation in this station is $1539 \mathrm{~mm}$. Most of the study area drains to the north to the Mero and the Barcés river basins (Fig. 1). However, a small area drains to the south and tributes to the Tambre River. The drainage network is very dense.

The study area is mostly framed in metapsamites and metapelites of the Betanzos-Arzúa Unit (Fig. 2), which is part of the Complex of Ordes, a polymetamorphic unit with intercalations of amphibolites and ultrabasic intrusions (Anthonioz and Ferragne 1978; Galán et al. 1978; Raposo et al. 2012). Narrow insertions of phyllites have been mapped in the south of the study area which are less than $4 \mathrm{~km}$ long. Quaternary colluvial and alluvial deposits are found in the lowest areas and in the flood plains of the main watercourses. Rock outcrops are hardy available for direct observation due to the covering by soil and abundant vegetation.

The rural study area has a low-density population ( 66 inhabitants per $\mathrm{km}^{2}$ ). The main land uses include pastures, thickets, forests and crops. The economy depends on agriculture, livestock and forestry with a few derived industries. The population in the study area does not have a public water supply system. Instead, the inhabitants rely on autonomous groundwater supply systems based on spring catchments and dug and drilling wells.

\section{Materials and methods}

\section{Electrical resistivity}

Geophysical techniques provide a tool to improve the knowledge about spatial heterogeneity in hard rocks. The electrical resistivity tomography (ERT) is a rapid method for determining the spatial distribution of the electrical resistivity in the subsurface, which can be linked to the variations in the clay content, rock porosity, water saturation and the concentration of dissolved electrolytes (Loke et al. 2003; Cassidy et al. 2014). The multi electrode dipole-dipole array allows for a large spacing between the 


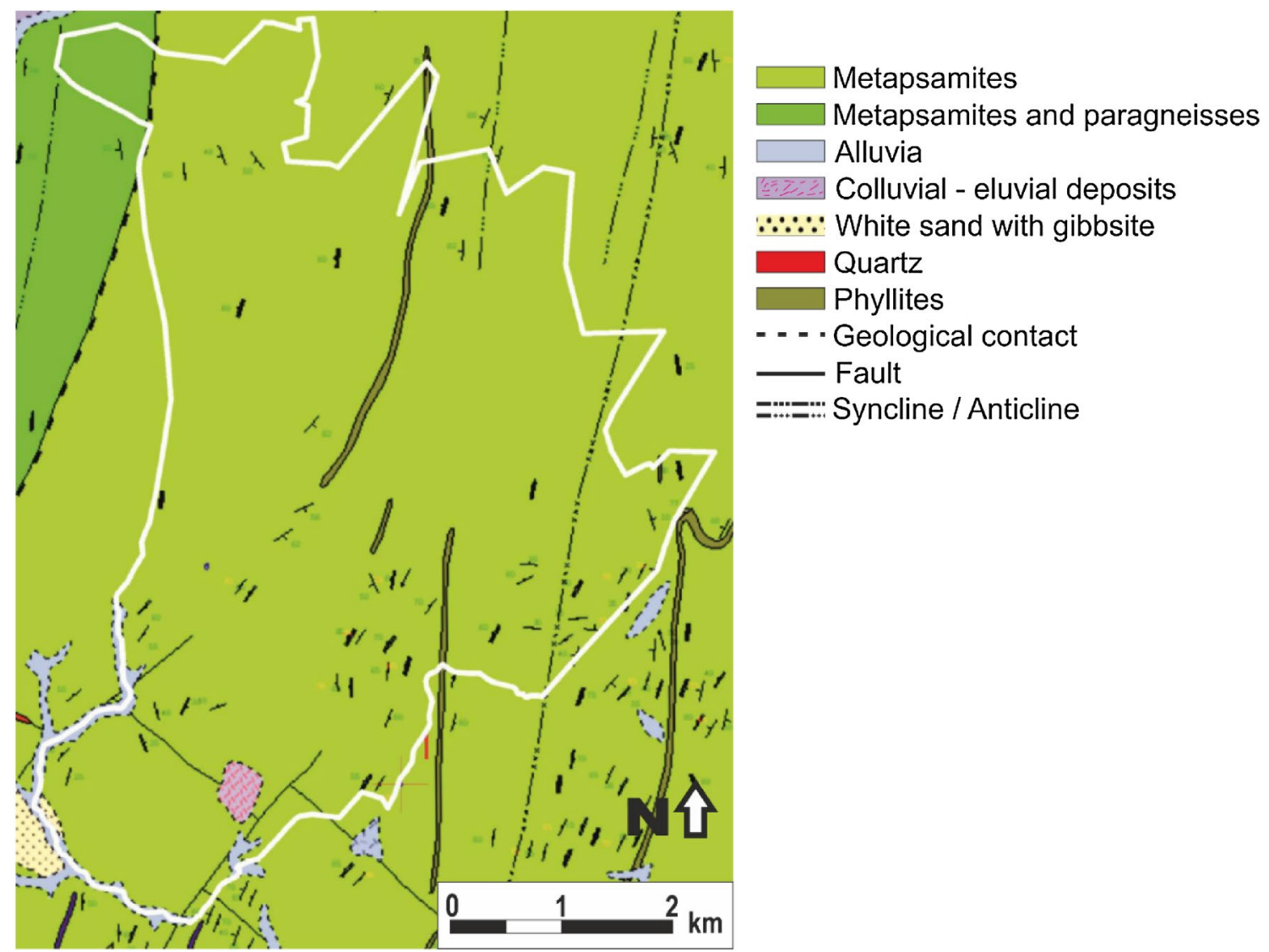

Fig. 2 Geological map and boundary of the study area (white line)

survey lines while still containing significant 3D information (Loke 2016). The dipole-dipole array is very sensitive to the horizontal changes in resistivity, but relatively insensitive to the vertical changes in the resistivity. Thus, it is well suited for mapping vertical structures (Loke 2016). According to Samouëlian et al. (2005), this array allows obtaining a depth of investigation larger than that of the Wenner and Schlumberger arrays. However, it has the disadvantage of a lower signal strength.

A 3D electrical resistivity tomography was performed in the Abegondo study area using the ABEM Lund Imaging system and a multi electrode dipole-dipole array with 40 electrodes and $5 \mathrm{~m}$ inter-electrode spacing. Five parallel survey lines with a separation of $10 \mathrm{~m}$ were performed in the southwest part of the study area near Wells 1 and 2 (Fig. 3). The actual subsurface resistivity was derived from the apparent resistivity values by solving the inverse problem with the RES3DINV software (Loke 2016) and by accounting for the ground topography. The results of the inversion of the ERT data file were post-processed with the Voxler 3D data visualization package software of Golden Software, Inc.

\section{Piezometric data and hydraulic tests}

An inventory of domestic dug and drilling wells, natural springs, and spring catchments for rural water supplies was performed in the study area. The location of the 133 water points is shown in Fig. 4. Three piezometers were drilled to monitor hydraulic heads and groundwater quality (Fig. 1). They were equipped with electrical pressure transducers to monitor continuously the water table depth.

Pumping tests were performed at two locations. The first one consisted on a constant-rate pumping test performed in a $30 \mathrm{~m}$ deep drilled well. The well is slotted in the deepest $15 \mathrm{~m}$. The pumped flowrate was $\sim 0.5 \mathrm{~L} / \mathrm{s}$ and pumping lasted for $2 \mathrm{~h}$. No observation wells were available. The water level was recorded with a manual piezometric probe during the pumping and recovery stages. The effective transmissivity of the regolith and highly fractured schist was derived using the Cooper-Jacob semi-log method. A second pumping test 

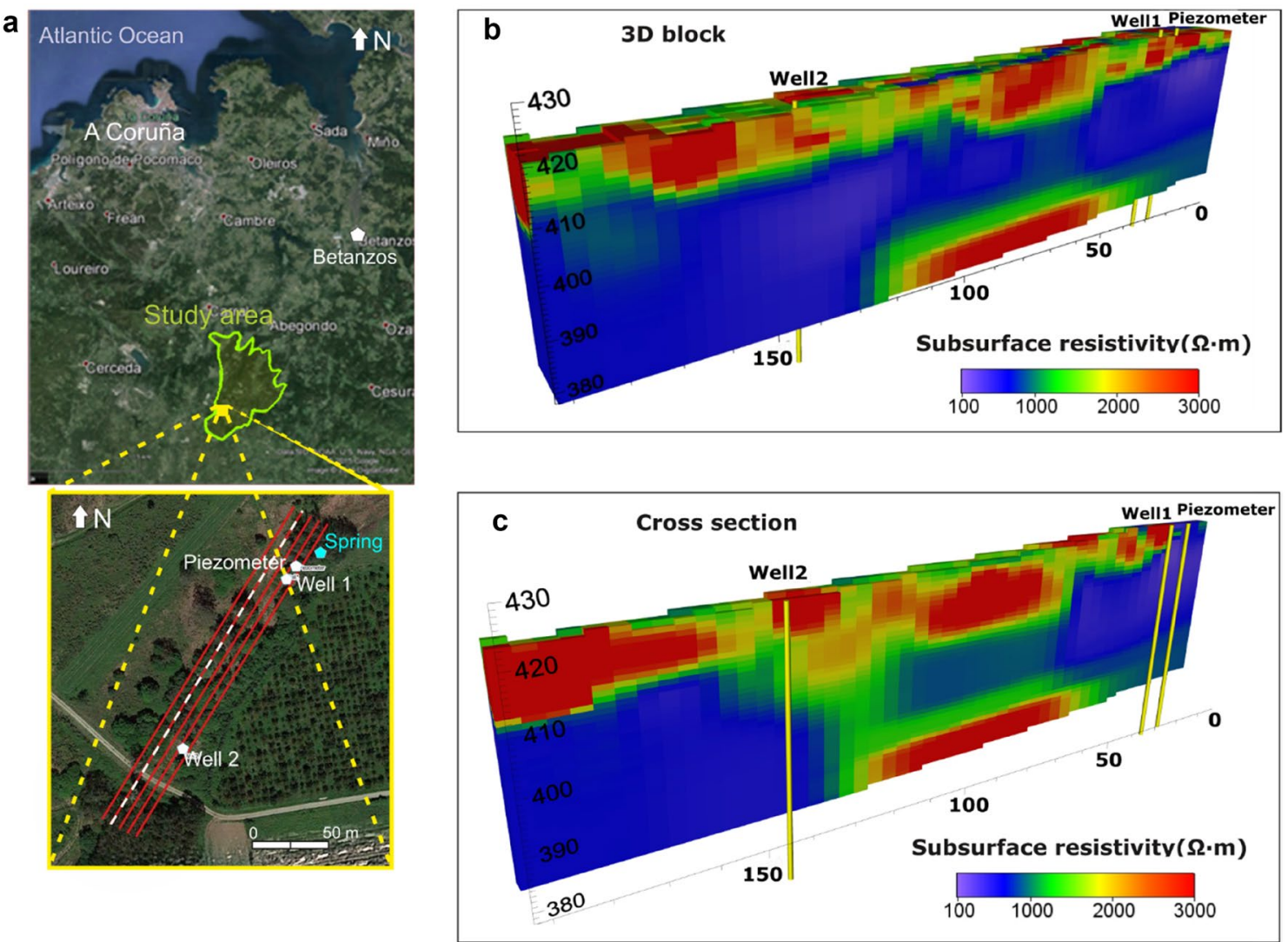

Fig. 3 Map of the study area with the location of the resistivity profiles, Wells 1 and 2 and the piezometer (a). 3D Electric Resistivity Tomography: Inverted subsurface resistivity $(\Omega \cdot \mathrm{m})$ for the $3 \mathrm{D}$ block $(\mathbf{b})$ and inverted resistivity $(\Omega \cdot \mathrm{m})$ in a cross section along the second dashed line $(\mathbf{c})$

was performed in a $27 \mathrm{~m}$ deep drilled well located in the South of the study area. Pumping lasted $25 \mathrm{~h}$ at a rate of $\sim 0.5$ $\mathrm{L} / \mathrm{s}$. Drawdowns were recorded during pumping and recovery at the pumping well and four observation wells using both manual piezometric probes and pressure transducers. The distances of the observation wells from the pumping well range from 27 to $78 \mathrm{~m}$. Estimates of the transmissivity and storativity were derived from the interpretation of drawdowns using the Theis type-curve and the Cooper-Jacob semi-log methods.

\section{Hydrological water balance}

The water resources of the study area were evaluated with a hydrological water balance performed with VISUAL BALAN (Samper et al. 2015a, b), a semi-distributed hydrological code that computes daily water balances in the upper-most soil layer, the unsaturated zone and the aquifer. VISUAL BALAN calculates sequentially the daily values of the components of the water balance. The daily water balance equation in the soil is given by (Pisani et al. 2019):
$\Delta \theta=P+I_{r}-I_{n}-\mathrm{AET}-S-R_{p}$,

where $\Delta \theta$ is the change in soil water content, $P$ is precipitation, $I_{r}$ is irrigation water, $I_{n}$ is interception, AET is actual evapotranspiration, $S$ is surface runoff, and $R_{\mathrm{p}}$ is potential recharge, which is equal to groundwater recharge if there is no interflow.

The water balance in the unsaturated zone is given by:

$\Delta V_{u z}=R_{p}-Q_{r}-Q_{h}$,

where $V_{\mathrm{uz}}$ is the volume of water stored in the unsaturated zone and $Q_{\mathrm{h}}$ and $Q_{\mathrm{r}}$ are interflow and recharge, respectively, which are given by (Samper et al. 1999; Pisani et al. 2019):

$Q_{h}=\alpha_{h} V_{u z}$,

$Q_{r}=K_{v}+\alpha_{r} V_{u z}$

where $K_{\mathrm{v}}$ is the saturated vertical hydraulic conductivity and $\alpha_{h}$ and $\alpha_{r}$ are the recession coefficients of interflow and recharge, respectively. Groundwater flow in the aquifer in VISUAL BALAN is assumed to be uniform and normal to the discharge areas. Groundwater discharge, $Q_{d}$, is calculated 


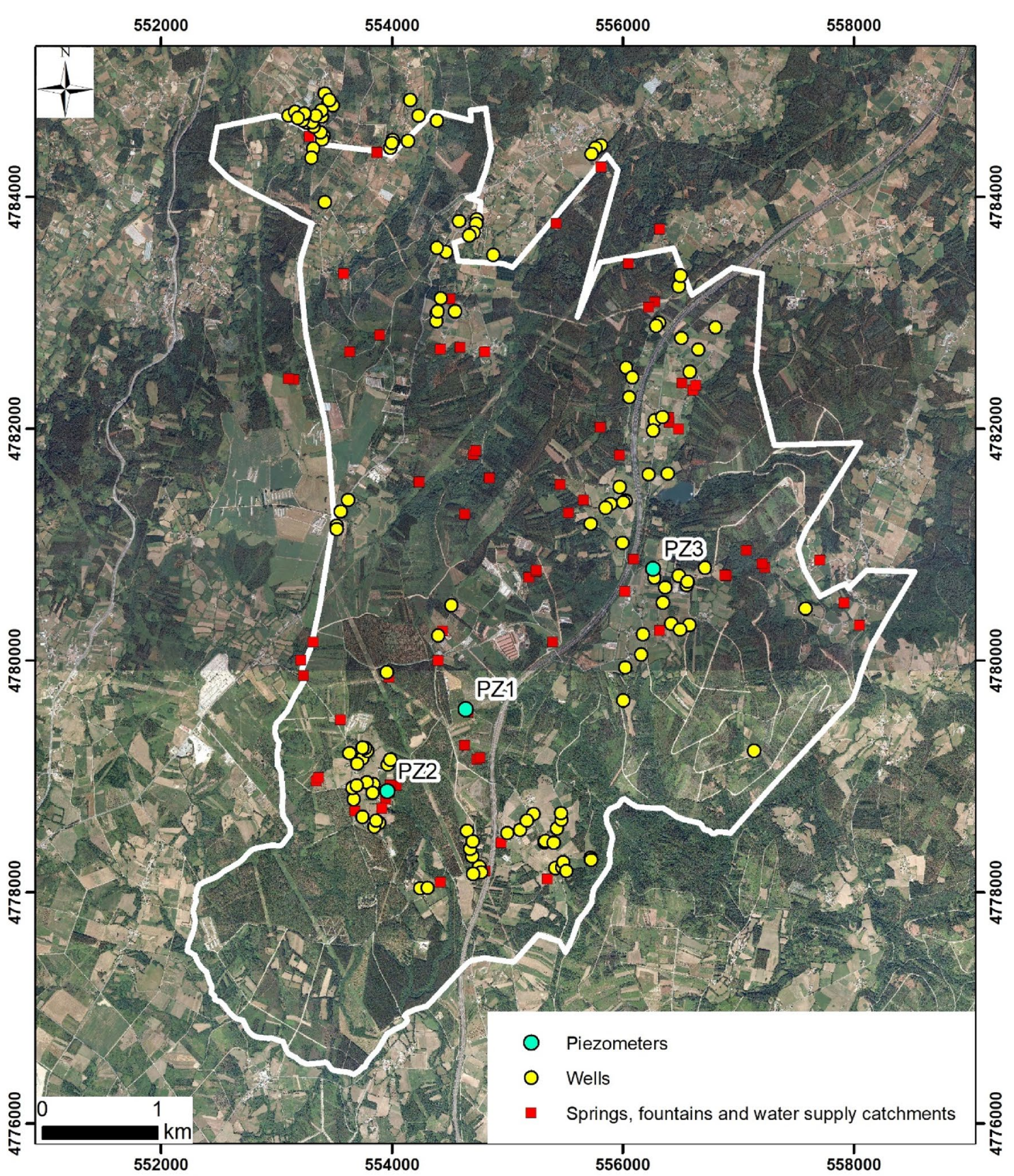

Fig. 4 Map of water points in the study area and the PZ1, PZ2, and PZ3 piezometers of the monitoring network

using a transient $1 \mathrm{D}$ explicit finite differences scheme. The total outflow from the basin is the sum of overland flow, $S$, interflow, $Q_{h}$, and groundwater discharge, $Q_{d}$. A detailed account of the methods and parameters of VISUAL BALAN can be found in Samper et al. (1999), Castañeda and GarcíaVera (2008), Samper and Pisani (2013) and Pisani et al. (2019).

Land use data were taken from CORINE maps (Bossard et al. 2000; https://land.copernicus.eu/pan-european/ corine-land-cover [last check: 09/09/2021]), aerial photos and field observations. The main types of land use in the study zone can be grouped into two main types: (1) Transition forest, mixed forest and thickets and (2) Crops. The water balance model was calibrated in four small basins. The first one corresponds to the Abelar pilot site, which is equipped with a piezometer and a gauging station (Fig. 1). The calibrated parameters of the hydrological model at the Abelar site were used as initial estimates for the models of the other three basins (Fig. 1), which are equipped each one of them with a piezometer (PZ1, PZ2 and PZ3 in 
Fig. 1). Soil, interception and evapotranspiration parameters were calibrated with piezometric data from February 2015 to September 2015 and by taking into account the vegetation and slope conditions of each zone.

\section{Evaluation of the impact of climate change}

Current global and regional climate models generally do not reproduce correctly the observed annual and monthly temperature and precipitation normals (3-decade averages) in the historical period. The bias of the simulations affects also the predictions for the future climate scenarios (Wilby et al. 2000; Stigter et al. 2014). This limitation is usually overcome by running hydrological models with the meteorological data provided by climatic models for both the control and the prediction periods. The impacts of the climate change were evaluated in terms of the differences between the results of the hydrological model in the control and the prediction periods (Akhtar et al. 2008). Although this method does not provide accurate predictions of the hydrological variables for the prediction period, it ensures that simulated climatic variables preserve the day-to-day variability (Hay et al. 2002; Wood et al. 2004).

The effects of climate change on the water resources at the end of the twenty-first century were evaluated for the A2 (more pessimistic) and the B2 (more optimistic) IPCC scenarios (Nakicenovic et al. 2000) with the precipitation and temperature predictions of the PROMES-HadAM3H climate model developed for the PRUDENCE European project (AEMET 2008; Christensen et al. 2007). The effects of climate change on the water resources for the period 2071-2100 were quantified using the hydrometeorological conditions of the reference historical period 1961-1990 and by assuming that the land use in the prediction period is the same as those in the control period. The meteorological series generated by the climate model for the control and prediction periods were used as inputs to the calibrated hydrological model of the study area. The results of the water balance in the control period were compared to those of the prediction period. The relative changes of the water balance components were calculated in a manner similar to Samper et al. (2015b), Espinha et al. (2010) and Pisani et al. (2019) who evaluated the effects of climate change in the Serra da Estrela hard-rock area in Portugal.

\section{Groundwater chemistry and pollution}

Groundwater quality was evaluated based on the results of 202 physicochemical and microbiological analyses performed on water samples from springs, domestic wells and piezometers within the study area from 2014 to 2016 (Aqua Plann 2011). The following chemical and microbiological parameters were determined: $\mathrm{pH}$, electric conductivity, the concentrations of major cations $\left(\mathrm{Na}^{+}, \mathrm{K}^{+}, \mathrm{Ca}^{2+}, \mathrm{Mg}^{2+}\right)$, major anions $\left(\mathrm{Cl}^{-}, \mathrm{SO}_{4}{ }^{2-}\right.$ and $\left.\mathrm{HCO}_{3}{ }^{-}\right)$, ammonium, nitrate, organic carbon, metals (Al, $\mathrm{As}, \mathrm{Cd}, \mathrm{Cu}, \mathrm{Cr}, \mathrm{Hg}, \mathrm{Ni}, \mathrm{Pb}, \mathrm{Se}$, $\mathrm{Zn}, \mathrm{Fe}, \mathrm{Mn}$ and $\mathrm{Sr}$ ), total and faecal coliform, E. coli and Faecal Streptococcus colonies.

The pristine chemical properties of the shallow groundwater in the study area were previously established within the framework of the LIFE Aqua Plann Project (Aqua Plann 2011; Naves et al. 2019). Measured concentrations were compared with the reference concentrations and the admissible (parametric) concentrations established in drinking water regulations (Directive 98/83/EC).

\section{Results}

\section{Geophysical results}

The resistivities obtained from the inversion of the ERT data range from 60 to about $3000 \Omega \cdot \mathrm{m}$, with large horizontal and vertical heterogeneities (Fig. 3). The resistivity is greater than $1500 \Omega \cdot \mathrm{m}$ in a shallow layer corresponding to the unsaturated regolith. The resistivity decreases sharply to less than $500 \Omega \cdot \mathrm{m}$, showing a sharp transition at depths ranging from 5 to $10 \mathrm{~m}$. This transition coincides with the location of the water table which is at $3 \mathrm{~m}$ depth in Well 1 and $6 \mathrm{~m}$ in Well 2. The thickness of the shallow high-resistivity zone decreases at the north-eastern corner near the spring.

High resistivities (up to $3000 \Omega \cdot \mathrm{m}$ ) are observed at the bottom of the 3D block between Wells 1 and 2. These large resistivities correspond to the slightly fractured schist. The zone of lower resistivities located below the water table and above the slightly fractured schist corresponds to the saturated regolith and highly fractured schist. The interpretation of the ERT does not allow distinguishing between both materials. This lumped layer extends beyond the depth of the resistivity profile $(\sim 40 \mathrm{~m})$ in most of the domain and its thickness is around $20 \mathrm{~m}$, where the slightly fractured schist can be observed.

The resistivity within the regolith and highly fractured schist shows spatial variability in both the longitudinal and the transversal directions. The observed heterogeneities in the resistivities are consistent with the measured depths to the water table and the water-producing layers in Wells 1 and 2 .

\section{Piezometric data and hydraulic tests}

Hydraulic head data show that the piezometric surface is shallow and smoothly follows the topographical surface. Its depth is less than $10 \mathrm{~m}$, except in the most elevated areas where it can exceed $20 \mathrm{~m}$ (Fig. 5). The measured 
Fig. 5 Scatterplot of average measured hydraulic heads and ground elevations $(z)$ in the recorded wells (top). Hydrograph of the water table elevation in piezometer PZ1 and daily precipitation from February 2015 to March 2017 (bottom)
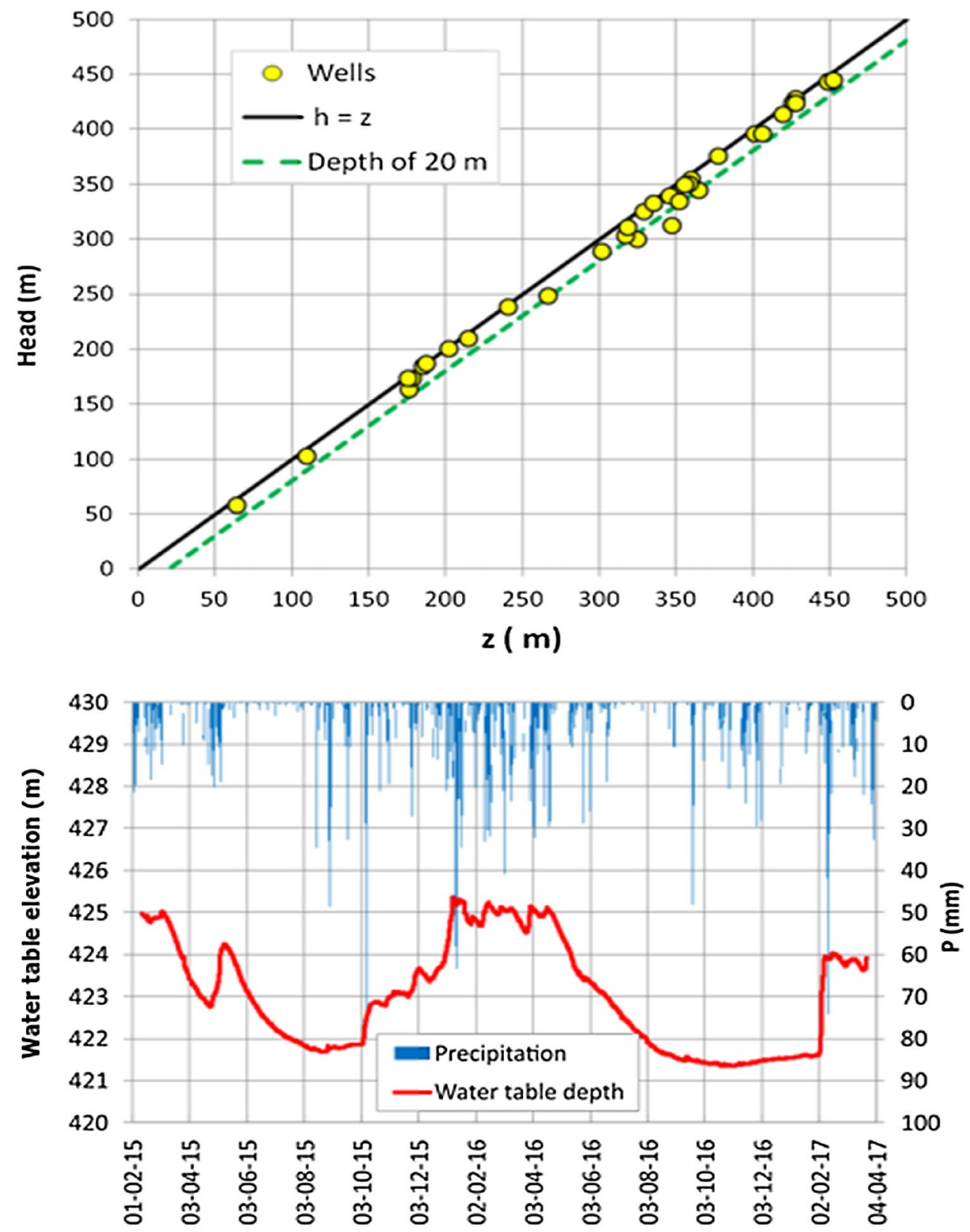

hydrographs in the three piezometers show that the water table rises in response to rainfall events. The seasonal oscillations of the hydraulic heads are smaller than $4 \mathrm{~m}$ (Fig. 5). Piezometric fluctuation data were not used to quantify groundwater recharge due to the difficulties of estimating groundwater recharge from water-table fluctuations in heterogeneous unconfined aquifers (Águila et al. 2019).

The estimated equivalent transmissivity of the lumped layer of regolith and highly fractured schist ranges from 15 to $35 \mathrm{~m}^{2} /$ days. These transmissivities are consistent with those reported by Carvalho et al. (2003) for the fractured schists in northern Portugal. These transmissivities are also consistent with those adopted by Naves et al. (2019) for modelling spring protection zones in Abegondo. The average specific yield of the regolith is 0.01 .

\section{Conceptualization of groundwater flow}

The conceptualization of the hydrogeology of the study area includes: (1) The regolith, (2) The decompressed highly fractured schist layer; and (3) The underlying slightly 
Fig. 6 Hydrogeological block diagram of the regolith, highly fractured and the less-fractured schists of Abegondo. Modified from Naves et al. (2019)

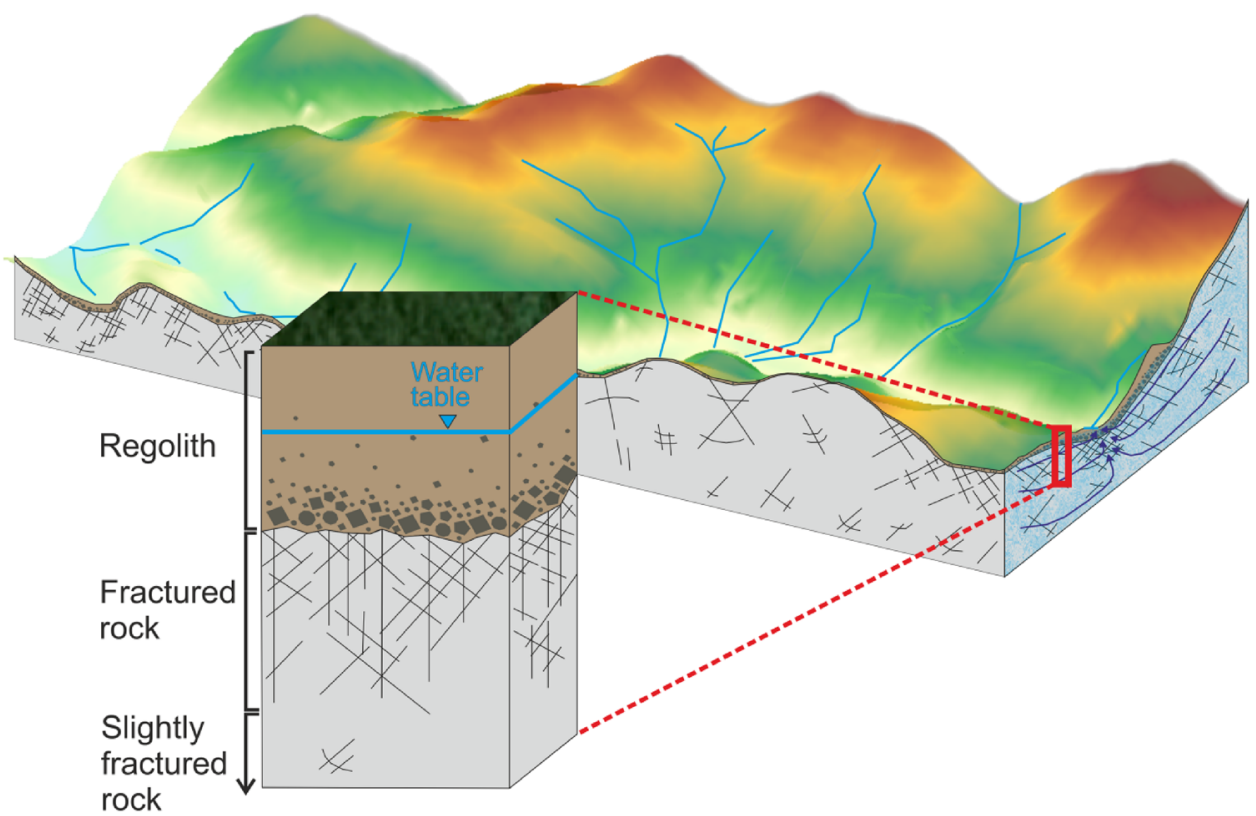

fractured schist (Fig. 6). The ERT results do not allow differentiating the regolith and the highly fractured schist. The measured thickness of both lumped layers range from 20 to $40 \mathrm{~m}$. These values are consistent with the information provided by well logs and the geological surveys conducted for the construction of the highway crossing the study area. This information states that: (1) The thickness of the schist regolith is spatially heterogeneous and ranges from 1 to $15 \mathrm{~m}$; and (2) The depth of the slightly fractured schist ranges from $15 \mathrm{~m}$ to more than $50 \mathrm{~m}$. No major fracture zones are present in the study area and the schists are highly fractured. These features tend to support the assumption that groundwater flow through the fractured schists obeys the equivalent porous media approach.

Most of the groundwater flows through the regolith and the highly fractured schist. Field evidences from borehole drilling have shown that groundwater flows into the drilled wells at the contact zone between the regolith and the highly fractured schist. The hydrogeological role of the slightly fractured schist can be generally neglected. The available data do not allow distinguishing the properties of the regolith and the highly fractured schist layers. Therefore, these two layers are lumped into a single unconfined aquifer with an equivalent transmissivity ranging from 15 to $35 \mathrm{~m}^{2} /$ day and a storativity of $\sim 0.01$.

Infiltration of rainwater is the source of aquifer recharge. Irrigation is restricted to small plots. Natural groundwater flow is slow ( $<1 \mathrm{~m} /$ day). The natural discharge of the groundwater occurs in seepage areas, springs, and the lower parts of the creeks and valleys. Springs are not found to be related to geological contacts, quartz dikes, tectonic fracture zones or other rock singularities. Flowpaths from recharge to discharge areas are generally short.

\section{Hydrological water balance}

The hydrological model of Abelar pilot basin was calibrated with measured stream flows at the watershed discharge point (Fig. 7a) and available piezometric data from October 2007 to September 2010. The mean annual values of the components of the water balance for the period 2006-2015 in the study area are listed in Table 1 . The average annual precipitation, $P$, is equal to $1499 \mathrm{~mm}$. Interception and actual evapotranspiration (AET) amount to $506 \mathrm{~mm}(34 \%$ of $P$ ). The remaining $66 \%$ of $P$ is the annual streamflow, $Q$. Interflow is the major component of $Q(78 \%)$. Groundwater recharge is $19 \%$ of $Q$ and surface runoff is about $3 \%$ of $Q$ (Table 1 ). The mean annual interflow is equal to $771 \mathrm{~mm}$ while the mean aquifer recharge is equal to $185 \mathrm{~mm}$. These values are consistent with those estimated by Raposo et al. (2012) with the chloride mass balance method.

\section{Effects of climate change on water resources and groundwater recharge}

The mean annual temperature in the period 2071-2100 could increase $2.4{ }^{\circ} \mathrm{C}$ in scenario B2 and $3.4{ }^{\circ} \mathrm{C}$ in scenario A2 compared to the mean temperature of $12.3^{\circ} \mathrm{C}$ in the control period. Table 1 shows the mean annual values of the components of the water balance in the study area in the control period (1961-1990) and the projected changes for the prediction period 2071-2100 caused by the climate change. Precipitation could decrease from 9 to $12.6 \%$. Although the potential 
Fig. 7 Measured (symbols) and computed (lines) stream flows at the discharge section of the Abelar site in 2007-2010 (a) and measured (symbols) and computed (lines) piezometric heads at the PZ2 piezometer in 2014-2015 (b)
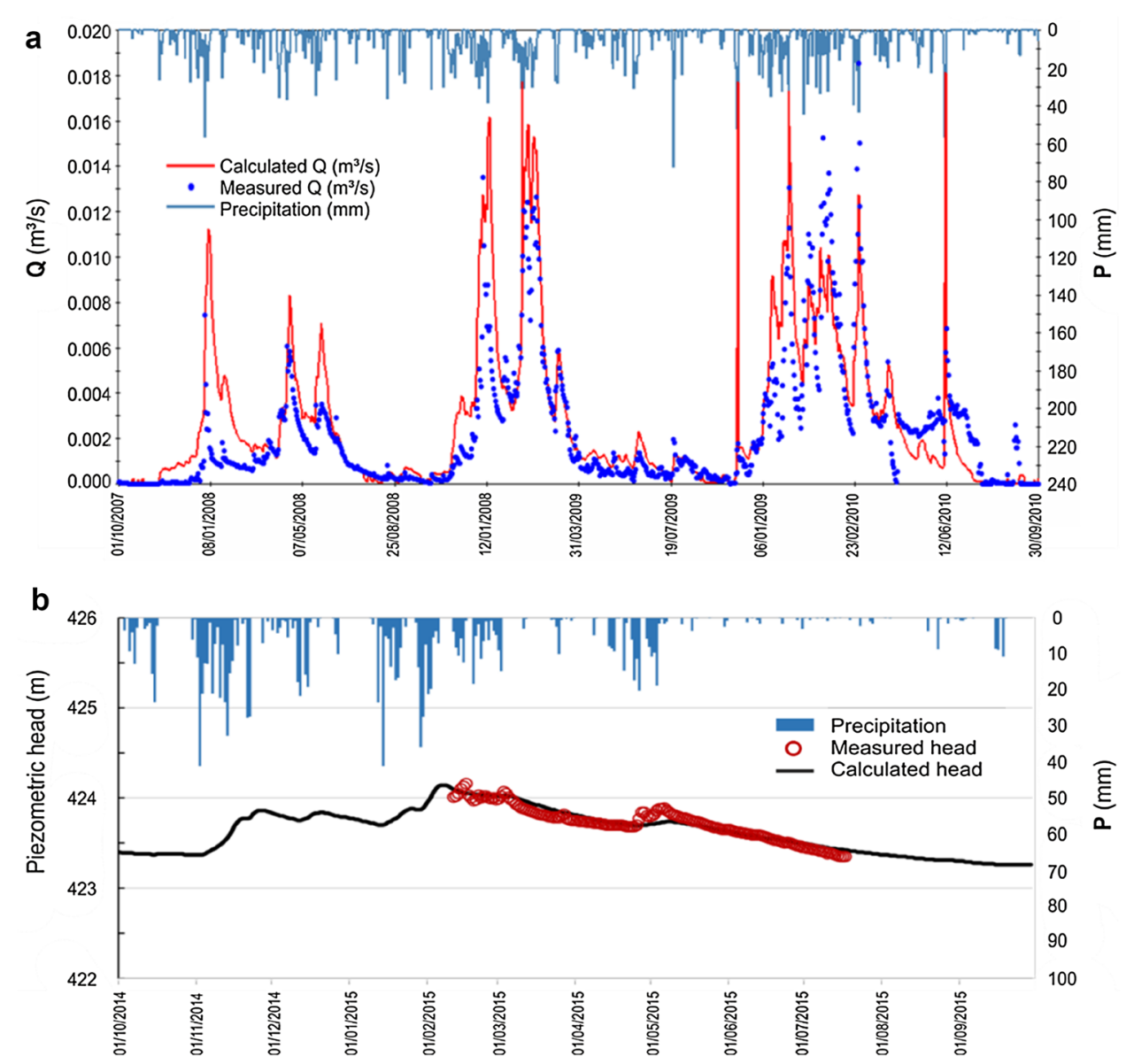

Table 1 Mean annual values of the components of the water balance calculated with the hydrological model for the historical period in the study area and in the Abelar pilot basin using historical meteorologi- cal data and predicted results and changes $(\Delta)$ in the mean annual values of the components of the water balance in the study area for the prediction period 2071-2100

\begin{tabular}{|c|c|c|c|c|c|c|c|}
\hline & \multirow{3}{*}{$\begin{array}{l}\text { Hydrological model of the } \\
\text { Abelar basin using historical } \\
\text { meteorological data } \\
\text { Historical period: } 2007-2010 \\
(\mathrm{~mm})\end{array}$} & \multirow{3}{*}{$\begin{array}{l}\text { Hydrological model of the } \\
\text { study area using historical } \\
\text { meteorological data } \\
\text { Historical period: } 2006-2015 \\
(\mathrm{~mm})\end{array}$} & \multicolumn{5}{|c|}{$\begin{array}{l}\text { Hydrological model of the study area using } \\
\text { meteorological data generated by climate } \\
\text { model simulations }\end{array}$} \\
\hline & & & \multirow{2}{*}{$\begin{array}{l}\text { Control } \\
\text { period } \\
1961-1990 \\
(\mathrm{~mm})\end{array}$} & \multicolumn{2}{|c|}{$\begin{array}{l}\text { Scenario A2 } \\
2071-2100\end{array}$} & \multicolumn{2}{|c|}{$\begin{array}{l}\text { Scenario B2 } \\
\text { 2071-2100 }\end{array}$} \\
\hline & & & & $(\mathrm{mm})$ & $\Delta(\%)$ & $(\mathrm{mm})$ & $\Delta(\%)$ \\
\hline Precipitation & 1597 & 1499 & 1272 & 1112 & -12.6 & 1158 & -9.0 \\
\hline Interception & 108 & 69 & 86 & 77 & -10.5 & 79 & -8.1 \\
\hline Potential recharge & 806 & 956 & 557 & 498 & -10.6 & 524 & -5.9 \\
\hline $\begin{array}{l}\text { Potential evapotranspiration } \\
\text { (PET) }\end{array}$ & 705 & 962 & 699 & 832 & 19.0 & 787 & 12.6 \\
\hline $\begin{array}{l}\text { Actual evapotranspiration } \\
\text { (AET) }\end{array}$ & 668 & 437 & 606 & 525 & -13.4 & 530 & -12.5 \\
\hline Surface runoff & 15 & 37 & 23 & 13 & -43.5 & 24 & 4.3 \\
\hline Interflow & 632 & 771 & 437 & 391 & -10.5 & 411 & -5.9 \\
\hline Groundwater recharge & 174 & 185 & 120 & 108 & -10.0 & 113 & -5.8 \\
\hline Streamflow & 821 & 993 & 580 & 511 & -11.9 & 548 & -5.5 \\
\hline
\end{tabular}


evapotranspiration could increase from 12.6 to $19 \%$, the actual evapotranspiration could decrease from 12.5 to $13.4 \%$ due to the decrease in precipitation (see Table 1). Groundwater recharge could decrease from 6 to 10\%. This reduction should not affect the availability of groundwater resources because groundwater use in the study area is much smaller than the average resources. A slight decline of groundwater levels and spring and fountain flows is expected. Recharge could increase in the winter and decrease in the rest of the year. The periods without recharge could become more frequent and last longer. Climate change could aggravate the problems of guarantee of water supply from spring catchments in droughts. Moreover, the effects of climate change could aggravate the decline of groundwater levels and the reduction of groundwater resources caused by the water consumption of eucalyptus plantations. For the most part, our predictions of climate change effects on water resources are consistent with those reported by Raposo et al. (2013).

\section{Groundwater quality and pollution}

The measured $\mathrm{pH}$ ranges from 5.7 to 6.5 . These slightly acidic values are similar to the $\mathrm{pH}$ of natural groundwater in the study area. The measured electrical conductivities are low and slightly larger than the reference values for this area (from 40 to $110 \mu \mathrm{S} / \mathrm{cm}$ ). The measured $\mathrm{pH}$, electrical conductivity and chloride concentration do not show significant spatial variability.

The natural concentration of dissolved nitrate ranges from 1 to $10.4 \mathrm{mg} / \mathrm{L}$ (Aqua Plann 2011). The nitrate concentrations measured in existing wells attest groundwater nitrate contamination in the southern part of the study area (Fig. 8). The upper regolith layer forms a shallow water table aquifer, which lacks a confining layer. These conditions do not provide a good natural protection against groundwater nitrate pollution.

The analysis of the pressures on the aquifer show that groundwater nitrate pollution is caused by the poor management of the manure in the fields and occasional discharges in pastures of large volumes of pig and mink slurries from local farms. Figure 8 clearly shows that most of the wells and springs affected by nitrate contamination are located near the areas with a large density of rural estates authorized for slurry discharge.

The measured total concentrations of some metals such as $\mathrm{Al}, \mathrm{Mn}, \mathrm{Fe}$, As and $\mathrm{Pb}$ exceed the parametric values for drinking water in some water points, when water samples are not properly filtered in situ. This pollution is generally associated with suspended matter. Dissolved metal concentrations are below their parametric values. Therefore, metal pollution can be easily prevented by groundwater filtration. Other metals such as arsenic, copper, cadmium, nickel, mercury, lead and zinc are found in very low concentrations.

\section{Recommendations for groundwater management and protection}

The extensive bacteriological contamination of groundwater in the study area could be overcome by appropriate filtering and chlorination. Filtering should also prevent groundwater metal pollution. Nitrate contamination, however, cannot be eliminated with a reasonable cost treatment. Alternative groundwater supply catchments for communities affected by nitrate pollution could be found in areas where appropriate land use planning measures are implemented to preserve groundwater quality.

Land use planning and groundwater protection regulations should be established based on a common consensus among all the involved stakeholders such as local and regional authorities, environmental, water and agriculture planners, pig breeders, farmers and water users. The discharge of slurry by farmers in rural states should take into account groundwater resources planning and management.

\section{Conclusions}

The study of the sustainability of groundwater supply in the rural areas of Abegondo municipality (Galicia, Spain) has been presented. The conceptualization of the hydrogeology of the study area includes: (1) The regolith, (2) The decompressed highly fractured schist layer; and (3) The underlying slightly fractured schist. Most of the groundwater flows through the two shallowest layers. The equivalent transmissivity of the regolith and the highly fractured schist layer ranges from 15 to $35 \mathrm{~m}^{2} /$ days. Infiltration of rainwater is the source of groundwater recharge. Creeks and the lowest valleys are discharge zones.

A hydrological water balance model has been constructed to evaluate the water resources in historical conditions. It has been calibrated using measured streamflow and piezometric data. The average groundwater recharge in the study area in the historical period (2006-2015) is $185 \mathrm{~mm} / \mathrm{year}$, which constitutes $12 \%$ of the average precipitation. The hydrological model was used to evaluate the effects of climate change at the end of the twenty-first century for the A2 (more pessimistic) and B2 (more optimistic) IPCC emission scenarios. Groundwater resources could decrease from 6 to $10 \%$ by the end of the twenty-first century. The reduction in groundwater resources could lead to a decline of groundwater levels and spring flows, especially in droughts. The expected decline in groundwater resources at the end of the twenty-first century due to climate change should not affect the availability of groundwater resources because current groundwater use in the study area is much smaller than the average resources. However, the water supply shortages in droughts could get 


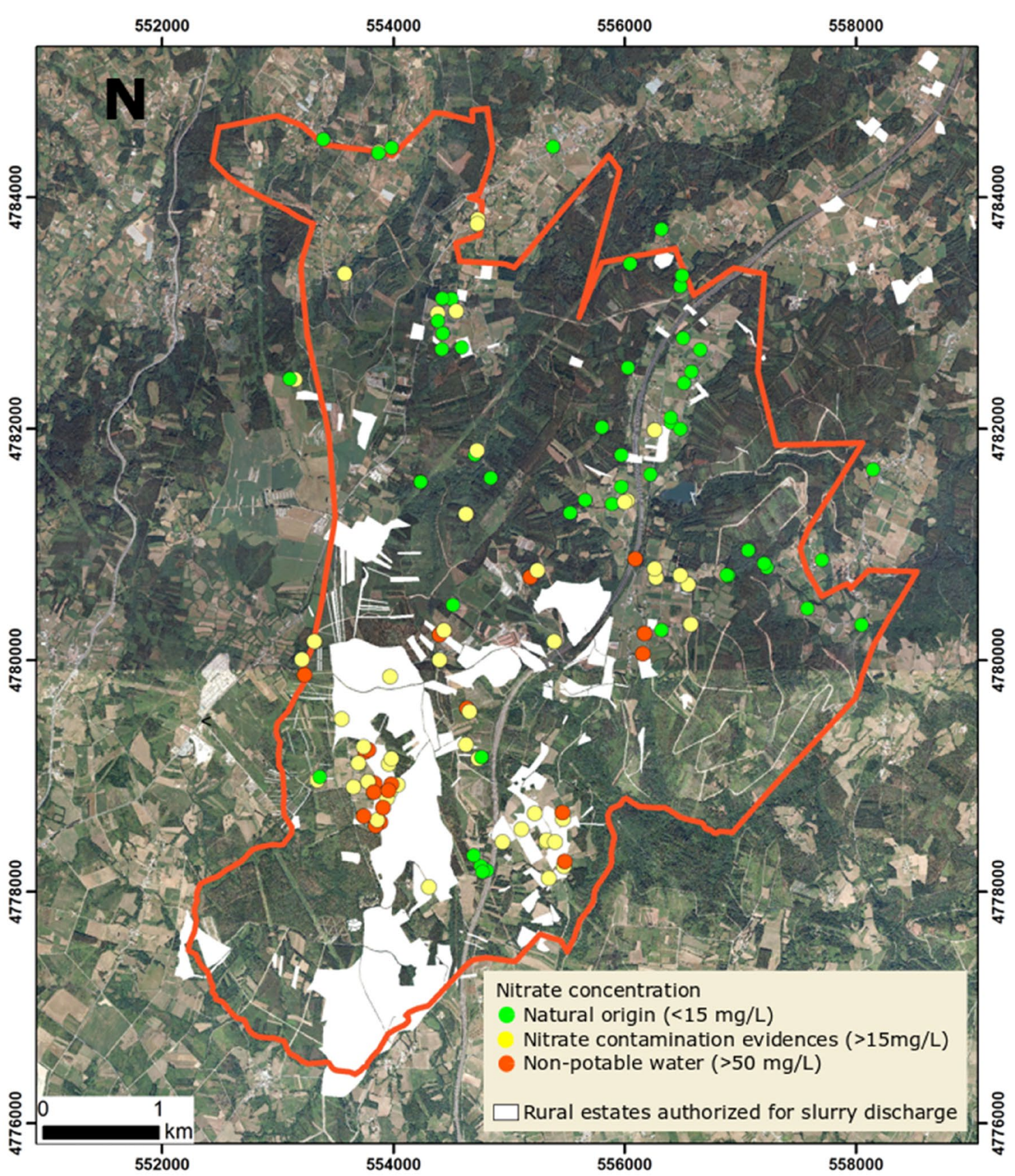

Fig. 8 Map of nitrate pollution classes in the study area, which indicates the points without evidence of pollution (green dots), with mild nitrate pollution (yellow dots) and exceeding the admissible limit (red

worse. Shortages could be overcome by deepening the water catchments or drilling deep wells.

Groundwater in the study area is slightly acidic and has low electrical conductivity. Some wells and springs show bacteriological and nitrate contamination caused by inadequate management of the manure in the fields and occasional discharges of slurry from local pig and mink farms. Measured total concentrations of some metals, related to dots). The rural estates authorized for slurry discharge by the regional environmental authority (white areas) are also shown

suspended matter, exceed their parametric values in some locations.

Filtering and chlorination should avoid groundwater bacteriological and metal pollution. Furthermore, appropriate management plans and groundwater protection actions are strongly recommended to prevent groundwater pollution and achieve a sustainable groundwater supply in the study area. 
The hydrological water balance model for recharge estimation and the conceptualization of groundwater flow presented here could be extended in future studies by performing a numerical groundwater flow and contaminant transport model.

Acknowledgements This work has been performed within the framework of the project "Sustainable solutions for small networks of supply" of the LIFE program of the European Commission, its partners being: The Galician Water Authority ("Augas de Galicia"), the Regional Health Department and the Municipality of Abegondo. We acknowledge the support provided by Carlos Ameijenda, Raquel Piñeiro, Mónica Velo, Roberto Arias, Elvira Íñiguez and SAI-UDC Services. The work has been funded also by a project of the Spanish Ministry of Science and Innovation (PID2019-109544RB-I00), and the Galician Regional Government (Grant number ED431C2021/54 from "Consolidación e estruturación de unidades de investigación competitivas", Grupos de referencia competitiva).

Funding Open Access funding provided thanks to the CRUE-CSIC agreement (Universidade da Coruña/CISUG) with Springer Nature. This study is funded by LIFE program of the European Commission, LIFE12 ENV/ES/000557, Ministerio de Ciencia e Innovación, PID2019-109544RB-I00, Consellería de Cultura, Educación e Ordenación Universitaria, Xunta de Galicia, ED431C 2017/67.

\section{Declarations}

Conflict of interest No conflicts of interests. No additional data or material.

Open Access This article is licensed under a Creative Commons Attribution 4.0 International License, which permits use, sharing, adaptation, distribution and reproduction in any medium or format, as long as you give appropriate credit to the original author(s) and the source, provide a link to the Creative Commons licence, and indicate if changes were made. The images or other third party material in this article are included in the article's Creative Commons licence, unless indicated otherwise in a credit line to the material. If material is not included in the article's Creative Commons licence and your intended use is not permitted by statutory regulation or exceeds the permitted use, you will need to obtain permission directly from the copyright holder. To view a copy of this licence, visit http://creativecommons.org/licenses/by/4.0/.

\section{References}

AEMET (2008) Generación de escenarios regionalizados de cambio climático para España, Agencia Estatal de Meteorología, http:// www.aemet.es/documentos/es/idi/clima/escenarios_CC/progr ama_coordinado_escenarios_final.pdf [in Spanish]. Accessed 6 Apr 2021

AEMET IM (2011) Iberian climate atlas. Air temperature and precipitation (1971-2000). Edited by: Agencia Estatal de Meteorología de España (AEMET) of Ministerio de Medio Ambiente y Medio Rural y Marino and Instituto de Meteorologia de Portugal (IM). ISBN: 978-84-7837-079-5. http://www.aemet.es/documentos/ es/divulgacion/publicaciones/Atlas-climatologico/Atlas.pdf. Accessed 6 Apr 2021

Águila JF, Samper J, Pisani B (2019) Parametric and numerical analysis of the estimation of groundwater recharge from water-table fluctuations in heterogeneous unconfined aquifers. Hydrogeol J 27:1309-1328. https://doi.org/10.1007/s10040-018-1908-x

Akhtar M, Ahmad N, Booij MJ (2008) The impact of climate change on the water resources of Hindukush-Karakorum-Himalaya region under different glacier coverage scenarios. J Hydrol 355:148-163. https://doi.org/10.1016/j.jhydrol.2008.03.015

Anthonioz P, Ferragne A (1978) Le Precambrien Polimetamorphique Allochtone de la Peninsule Iberique, temoin d'une nappe charriage Caledonienne. Cuad Sem Est Cerámicos De Sargadelos 27:24-41 (in French)

Aqua Plann (2011) Diagnosis and detailed study of the current state of groundwater quality in the Mero-Barcés basin/Proyecto Aqua Plann Porject, Final Report of Activity A.3-Municipality of Abegondo. June 2011 (in Spanish)

Barenblatt G, Zheltov I, Kochina I (1960) Basic concepts in the theory of homogeneous liquids in fissured rocks. J Appl Math Mech, USSR 24(5):1286-1303

Bear J (1993) Modeling flow and contaminant transport in fractured rocks. In: Bear J, Tsang C, de Marsily G (eds) Flow and contaminant transport in fractured rocks. Academic Press, San Diego, pp $1-36$

Berkowitz B (2002) Characterizing flow and transport in fractured geological media: a review. Adv Water Resour 25(8-12):861-884. https://doi.org/10.1016/S0309-1708(02)00042-8

Bossard M, Feranec J, Otahel J (2000) Corine land cover technical guide-Addendum 2000, EEA Technical, Report 40

Carvalho JM, Chaminé HI, Plasencia N (2003) Caracterização dos recursos hídricos subterrâneos do maciço cristalino do Norte de Portugal: implicações para o desenvolvimento regional. In: A Geologia de Engenharia e os Recursos Geológicos: recursos geológicos e formação. Volume de Homenagem ao Prof. Doutor Cotelo Neiva. Série Investigação Imprensa da Universidade de Coimbra, Vol. 2, 245-264. ISBN: 972-8704-15-1. https://doi.org/ 10.14195/978-989-26-0322-3_18 (in Portuguese)

Cassidy R, Comte J-C, Nitsche J, Wilson C, Flynn R, Ofterdinger U (2014) Combining multi-scale geophysical techniques for robust hydro-structural characterisation in catchments underlain by hard rock in post-glacial regions. J Hydrol 517:715-731. https://doi. org/10.1016/j.jhydrol.2014.06.004

Castañeda C, García-Vera MA (2008) Water balance in the playalakes of an arid environment, Monegros, NE Spain. Hydrogeol J 16:87-102

Christensen JH, Carter TR, Rummukainen M, Amanatidis G (2007) Evaluating the performance and utility of regional climate models: the PRUDENCE project. Clim Change 81(suppl. 1):1-6. https:// doi.org/10.1007/s10584-006-9211-6

Dewandel B, Lachassagne P, Wynns R, Maréchal JC, Krishnamurthy NS (2006) A generalized 3-D geological and hydrogeological conceptual model of granite aquifers controlled by single or multiphase weathering. J Hydrol 330:260-284. https://doi.org/10. 1016/j.jhydrol.2006.03.026

Dong Y, Fu Y, Yeh TJ, Wang Y, Zha Y, Wang L, Hao Y (2019) Equivalence of discrete fracture network and porous media models by hydraulic tomography. Water Resour Res. https://doi.org/10.1029/ 2018WR024290

EC (2010) Report from the Commission in accordance with Article 3.7 of the Groundwater Directive 2006/118/EC on the establishment of groundwater threshold values, 5.3.2010 C 1096 final, European Commission, Brussels, $\mathrm{p} 10$

Espinha MJ, Samper J, Pisani B, Alvares D, Carvalho JM, Chaminé HI, Marques JM, Vieira GT, Mora C, Sodré Borges F (2010) Evaluation of water resources in a high-mountain basin in Serra da Estrela, Central Portugal, using a semi-distributed hydrological model. Environ Earth Sci 62(6):1219-1234. https://doi.org/10. 1007/s12665-010-0610-7 
Espinha Marques J, Marques JM, Chaminé HI, Carreira PM, Fonseca PE, Monteiro Santos FA, Moura R, Samper J, Pisani B, Teixeira J, Carvalho JM, Rocha F, Borges FS (2013) Conceptualizing a mountain hydrogeologic system by using an integrated groundwater assessment (Serra da Estrela, Central Portugal): a review. Geosci J 17(3):371-386. https://doi.org/10.1007/s12303-013-0019-x

Galán J, Aldaya F, Ruiz F, Huerga A (1978) Mapa geológico y Memoria de la Hoja $n^{\circ} 45$ (5-5) Betanzos, Mapa Geológico de España E. 1:200.000, Instituto Tecnológico Geominero de España (ITGE), p 284, Legal Deposit: M-24423-1989. NIPO: 232-89-011-1. (in Spanish)

Hay LE, Clark MP, Wilby RL, Gutowski WJ, Leavesley GH, Pan Z, Arritt RW, Takle ES (2002) Use of regional climate model output for hydrologic simulations. J Hydrometeorol 3:571-590. https:// doi.org/10.1175/1525-7541(2002)003\%3c0571:UORCMO\% 3e2.0.CO;2

Krasny J (2002) Quantitative hardrock hydrogeology in a regional scale. Norges Geol Unders Bull 439:7-14

Lee C-H, Farmer I (1993) Fluid flow in discontinuous rocks. Chapman \& Hall, London

Life Rural Supplies (2020). https://ruralsupplies.eu/ Accessed 6 Apr 2021

Loke I (2016) Tutorial: 2D and 3D electrical imaging surveys, Geotomosoft Course Notes, www.geotomosoft.com. Accessed 6 Apr 2021

Loke I, Acworth T, Dahlin A (2003) Comparison of smooth and blocky inversion methods in 2D electrical imaging surveys. Explor Geophys 34(3):182-187. https://doi.org/10.1071/EG03182

Long JCS, Remer JS, Wilson CR, Witherspoon PA (1982) Porous media equivalents for networks of discontinuous fractures. Water Resour Res 18(3):645-658. https://doi.org/10.1029/WR018i003p 00645

Lubczynski MW, Gurwin J (2005) Integration of various data sources for transient groundwater modeling with spatio-temporally variable fluxes-Sardon study case, Spain. J Hydrol 306:71-96. https:// doi.org/10.1016/j.jhydrol.2004.08.038

Molinero J, Samper J (2004) Groundwater flow and solute transport in fracture zones: an improved model for a large-scale field experiment at Äspö (Sweden). J Hydraul Res 42(2):157-172

Molinero JJ, Samper GZ, Yang C (2004) Biogeochemical reactive transport model of the redox zone experiment of the Äspö hard rock laboratory in Sweden. Nucl Technol 148:151-165

Nakicenovic N, Alcamo J, Davis G, de Vries B, Fenhann J, Gaffin S, Gregory K, Grübler A, Jung TY, Kram T, La Rovere EL, Michaelis L, Mori S, Morita T, Pepper W, Pitcher H, Price L, Riahi K, Roehrl A, Rogner H-H, Sankovski A, Schlesinger M, Shukla P, Smith S, Swart R, van Rooijen R, Victor N, Dadi Z (2000) IPCC special report on emission scenarios. Cambridge University Press, Cambridge and New York, p 570

Naves A, Varela-Álvarez EJ (2021) Community-owned rural water supplies in Galicia (Spain): supporting role in the groundwater self-management. Mediterr Geosci Rev. https://doi.org/10.1007/ s42990-021-00068-3

Naves A, Samper J, Mon A, Pisani B, Montenegro L, Carvalho JM (2019) Demonstrative actions of spring restoration and groundwater protection in rural areas of Abegondo (Galicia, Spain). Sustain Water Resour Manag 5:175-186. https://doi.org/10.1007/ s40899-017-0169-5

Naves A, Samper J, Pisani B, Mon A, Dafonte J, Montenegro L, García A (2021) Hydrogeology and groundwater management in a coastal granitic area with steep slopes in Galicia (Spain) Spain). Hydrogeol J. https://doi.org/10.1007/s10040-021-02349-5

Pisani B, Samper J, Espinha-Marques J (2019) Climate change impact on groundwater resources of a hard rock mountain region (Serra da Estrela, Central Portugal). Sustain Water Resour Manag 5:289_ 304. https://doi.org/10.1007/s40899-017-0129-0
Raposo JR, Molinero J, Dafonte J (2012) Parameterization and quantification of recharge in crystalline fractured bedrocks in GaliciaCosta (NW Spain). Hydrol Earth Syst Sci 16:1667-1683. https:// doi.org/10.5194/hess-16-1667-2012

Raposo J, Dafonte J, Molinero J (2013) Assessing the impact of future climate change on groundwater recharge in GaliciaCosta, Spain. Hydrogeol J 21:459-479. https://doi.org/10.1007/ s10040-012-0922-7

Rodríguez-Suárez JA, Soto B, Pérez R, Díaz-Fierros YF (2011) Influence of Eucalyptus globulus plantation growth on water table levels and low flows in a small catchment. J Hydrol 396(2011):321326. https://doi.org/10.1016/j.jhydrol.2010.11.027

Rodríguez-Suárez JA, Díaz-Fierros F, Pérez R, Soto YB (2014) Assessing the influence of afforestation with Eucalyptus globulus on hydrological response from a small catchment in northwestern Spain using the HBV hydrological model. Hydrol Process 28:5561-5572. https://doi.org/10.1002/hyp.10061

Samouëlian A, Cousin I, Tabbagh A, Bruand A, Richard G (2005) Electrical resistivity survey in soil science: a review. Soil Tillage Res. 83:173-193. https://doi.org/10.1016/j.still.2004.10.004

Samper FJ, Neuman SP (1989) Estimation of spatial covariance structures by adjoint-state maximum likelihood cross-validation: 2 . Synthetic Experiments. Water Resour Res 25(3):363-372

Samper J, Pisani B (2013) Balance hidrometeorológico e hidroquímico para el estudio de los recursos hídricos y la evolución de la calidad química del agua en pequeñas cuencas de Galicia. En: XI Jornadas de Estudios de la Zona No Saturada ZNS'13, Lugo, 235-242 (in Spanish)

Samper J, Huguet L, Ares J, García Vera MA (1999) Manual del usuario del programa VISUAL BALAN v1.0: código interactivo para la realización de balances hidrológicos y la estimación de la recarga (User manual of the program VISUAL BALAN v1.0: a user-friendly code to compute water balances and assess the aquifer recharge). Tech. Publ. ENRESA 05/99. Madrid. p 134 (in Spanish)

Samper J, Pisani B, Espinha Marques J (2015a) Hydrological models of interflow in three Iberian mountain basins. Environ Earth Sci 73:2645-2656. https://doi.org/10.1007/s12665-014-3676-9

Samper J, Li Y, Pisani B (2015b) An evaluation of climate change impacts on groundwater flow in the La Plana de la Galera and Tortosa alluvial aquifers (Spain). Environ Earth Sci 73:2595-2608. https://doi.org/10.1007/s12665-014-3734-3

Selroos J, Walker DD, Ström A, Gylling B, Follin S (2002) Comparison of alternative modelling approaches for groundwater flow in fractured rock. J Hydrol 257(1-4):174-188. https://doi.org/10.1016/ S0022-1694(01)00551-0

Soto B, Brea MA, Pérez R, Díaz-Fierros F (2005) Influence of 7-year old eucaliptus globulus plantation in the low flow of a small basin. In: The fourth Inter-Celtic Colloquium on Hydrology and Management of Water Resources, Guimarães, Portugal, pp 11-14 July, 2005

Stigter TY, Nunes JP, Pisani B, Fakir Y, Hugman R, Li Y, Tomé S, Ribeiro L, Samper J, Oliveira R, Monteiro JP, Silva A, Tavares PCF, Shapouri M, Cancela da Fonseca L, Himer El (2014) Comparative assessment of climate change impacts on coastal groundwater resources and dependent ecosystems in the Mediterranean. Reg Environ Change 14(Suppl 1):S41-S56. https://doi.org/10. 1007/s10113-012-0377-3

Taylor R, Howard K (2000) A tectono-geomorphic model of hydrogeology of deeply weathered crystalline rock: evidence from Uganda. Hydrogeol J 8:279-294. https://doi.org/10.1007/s100400000069

Wilby RL, Hay LE, Gutowski WJ Jr, Arritt RW, Takle ES, Pan Z, Leavesley GH, Clark MP (2000) Hydrological responses to dynamically and statistically downscaled climate model output. Geophys Res Lett 27:1199-1202. https://doi.org/10.1029/1999G L006078 
Wood AW, Leung LR, Sridhar V, Lettenmaier DP (2004) Hydrologic implications of dynamical and statistical approaches to downscaling climate model outputs. Clim Change 62:189-216. https://doi. org/10.1023/B:CLIM.0000013685.99609.9e
Publisher's Note Springer Nature remains neutral with regard to jurisdictional claims in published maps and institutional affiliations. 